Biografistyka Pedagogiczna

Rok 6 (2021) nr 2

ISSN 2543-6112; e-ISSN 2543-7399

DOI:10 .36578/BP.2021.06.42

\title{
Aneta Skuza*
}

\section{Działalność Czesława Czapówa w oddziałach partyzanckich na Kielecczyźnie w czasie drugiej wojny światowej (1939-1945)
C zesław Czapów Activity in Partisan Units in the Kielce Region during World War II (1939-1945)

\begin{abstract}
Czesław Czapów from the Uniwersity of Warsaw enrolled in the pages of Polish science as the creator of the Warsaw school of rehabilitation. In 2020, 40 years have passed scince his sudden, premature death. He left great scientific works, which until now constitute the basic reading in the field of rehabilitation sciences. He also remained in the memories of fellow colleagues who, however, do not really know much about his private life or his early years. The presented text aims to introduce one of the very interesting (completely unknown) threads in the life of Czesław Czapów, namely activity in partisan units during the Second World War in Kielcczyzna. At the same time, it is a part of a larger work related to him that is being prepared. The conducted research is part of the stream of qualitative research, and their specificity requires the use of a specific methodology of data collection, based on historical, biographical, historical and educational, historical and pedagogical research. I used a triangulation of methods and data. The source of information about Czesław Czapów's activities during World War II, on the basis of which I have compiled the following text, are source and archival materials, press articles, documents and photographs, an interview and the available literature on the subject.
\end{abstract}

Keywords: Narodowe Siły Zbrojne, Armia Krajowa, partisan units: Lotna Bojowa Sandomierska, Jędrusie.

* Aneta Skuza (ORCID: 0ooo-00o3-2120-8591) - dr, asystent w Instytucie Pedagogiki na Uniwersytecie Jana Kochanowskiegow Kielcach, kontakt: aneta.skuza@ujk.edu.pl. 
C zesław Czapów zapisał się na kartach polskiej myśli pedagogicznej jako twórca tzw. warszawskiej szkoły resocjalizacyjnej1. Trzeba tutaj podkreślić, iż niewątpliwą zasługą dr hab. Czesława Czapówa, profesora Uniwersytetu Warszawskiego było unaukowienie pedagogiki, jej ujęć teoretycznych i metodologicznych. Do swej pedagogiki resocjalizacyjnej zastosował prakseologiczną aparaturę pojęciową. Inspirował się także możliwościami, jakie dawała teoria systemów, cybernetyka oraz socjotechnika. Jego pedagogika to także pedagogika „pełna” humanistycznych i prospołecznych treści, które w precyzyjny sposób zostały zaprezentowane w publikacjach naukowych mających ogromne znaczenie dla rozwoju pedagogiki resocjalizacyjnej, przede wszystkim w dwóch: Wychowanie resocjalizujące. Elementy metodyki i diagnostyki ${ }^{2}$ i napisanej wraz z Stanisławem Jedlewskim Pedagogika resocjalizacyjna ${ }^{3}$.Źródłem Jego przekonań była koncepcja osoby oraz wartość cywilizacji budowanej na fundamencie chrześcijańskiego personalizmu - osoba wyraża całego człowieka, jest raczej dążeniem niż bytem, jest zdolna do przekraczania siebie i do wyrzeczeń; łączy swe powołanie i wcielanie idei z życiem we wspólnocie z innymi, otwartością wobec odmienności innego człowieka oraz tolerancją. Czesław Czapów to także współtwórca i autor koncepcji (było ich trzy) Instytutu Profilaktyki Społecznej i Resocjalizacji w Uniwersytecie Warszawskim, jednostki powołanej w $1971 \mathrm{r}$.

Jak napisał Jerzy Kwaśniewski: „dewizą Jego życia i pracy była prawda. Sam poszukiwał prawdy i wpajał innym przekonanie, że tylko na jej podstawie można uzdrowić stosunki międzyludzkie i zbudować przyszłość. Bez prawdy nie zaistnieje również miłość, a ujmował ją jako obowiązek i przywilej człowieka wobec człowieka, ludzi wobec ludzkości, jako istotę humanizmu"4.

Dla współczesnych adeptów nauk społecznych pozostał w pamięci dzięki swoim publikacjom - choć moim zdaniem obecnie skrzętnie omijanym. Niewątpliwie sięga się do nich przy specjalnych okazjach, twórczość Czapówa nie jest bowiem przedmiotem zainteresowania wielu naukowców. Kim był Czesław Cza-

1 Badania realizowane w ramach miniGRANTU 2019 - konkursu ogłoszonego w Uniwersytecie Jana Kochanowskiego w Kielcach na indywidualny projekt badawczy.

2 C. Czapów, Elementy metodyki i diagnostyki, Warszawa 1978.

3 C. Czapów, S. Jedlewski, Pedagogika resocjalizacyjna, Warszawa 1971.

4 J. Kwaśniewski, Takim Go zapamiętałem, w: Czesław Czapów 1925-1980: świadectwa trzech pokoleń, red. W. Kaczyńska, Warszawa 2003, s. 97. 
pów i jaki obraz pozostawił po sobie w sercach bliskich osób i współpracowników, można odkryć na kartach książki opracowanej i zredagowanej przez Wandę Kaczyńską ${ }^{5}$. Wracałam do niej bardzo często - wręcz stała się ona inspiracją do moich nieustannych poszukiwań materiałów pozwalających udokumentować losy Czapówa w partyzantce w latach 1943-1944 na Ziemi Kieleckiej. Ta praca nie powstałaby, gdyby nie życzliwość, pasja, wiedza osób, które do dziś pielęgnują pamięć o losach tysięcy polskich obywateli, którzy jesienią 1939 r. włączyli się obronę naszej ojczyzny. Przede wszystkim mam w pamięci Marię Dąbrowską, córkę legendarnego Eugeniusza Dąbrowskiego, autora chociażby znanej (i wielokrotnie wznawianej) wielu pokoleniom książki Szlakiem Jędrusiów ${ }^{6}$. To w dużej mierze dzięki jej zaangażowaniu i poszukiwaniach w dokumentach, które pozostały w jej domu, udało mi się zebrać wiele cennych materiałów. Podejmując się zadania udokumentowania działalności Czapówa w partyzantce na Kielecczyźnie, zastanawiałam się, mając świadomość wieku jego towarzyszy broni, czy uda się odnaleźć choć jedną osobę pamiętającą i współpracującą z nim w tamtym trudnym czasie, która opowie mi jakąś historię z nim związaną. Udało się i od tej opowieści rozpoczynam historię Czapówa.

\section{Narodowe Siły Zbrojne - najbardziej „wyklęci z wyklętych”}

Narodowe Siły Zbrojne (NSZ) w opatowskim i sandomierskim rekrutowały się głównie ze środowisk drobnomieszczańskich i inteligencji z Ostrowca, Opatowa, Sandomierza, Zawichostu, Koprzywnicy, Klimontowa. Dużą grupę stanowili także ziemianie z Bogusławic, Podola, Kaliszan, Mydłowa, Stodół. Ruch oporu osiągnął tam wysoki poziom organizacyjno-werbunkowy, powstała ogromna sieć komórek, placówek, rejonów, podobwodów, które stały się oparciem i bazami dla prowadzących walkę zbrojną oddziałów partyzanckich, specjalnych grup wypadowych, oddziałów taktycznych ${ }^{7}$. Na wsiach i w lasach zaczęły powstawać pierwsze leśne oddziały partyzanckie (ze względu na występujące

5 Czesław Czapów 1925-1980: świadectwa trzech pokoleń, zebr., oprac., red. W. Kaczyńska, Warszawa 2003.

6 E. Dąbrowski, Szlakiem Jędrusiów, Warszawa 1966.

7 P. Matusak, Ruch oporu na ziemi opatowsko-sandomierskiej w latach 1939-1945, Warszawa 1976, s. 225-230. 
tam dobre warunki terenowe - lasy świętokrzyskie i starachowickie). Na terenie Kielecczyzny były to oddziały partyzanckie poruczników: „Morskiego”, „Bema” czy „Groźnego” i wielu innych ${ }^{8}$.

I to właśnie w strukturach Nzs na terenie Sandomierza rozpoczą swą działalność partyzancką Czapów. 14 czerwca 2018 r. przeprowadziłam wywiad z dr. Januszem Kamockim pseudonim „Mamut”. To właśnie on pamięta Czapówa jako młodego chłopca, który w 1943 r. był sekcyjnym - szefem sześcioosobowej grupy, która weszła w skład NSz. Chciał wówczas do nich należeć także Janusz Kamocki. Pamięta on, jak udając się na pierwsze spotkanie z grupą dowodzoną przez Czapówa, musiał zapamiętać hasło, które jego zdaniem było nieprawdopodobnie trudne, a wręcz „niedorzeczne - stworzone na modłę warszawską”, a które pozwoliło na jego identyfikację i włączenie do grupy. Tych wspólnych spotkań było około sześciu i związane były one przede wszystkim z ćwiczeniem podstawowych komend - „to była taka zabawa w wojnę; sam był przerażony i nie wiedział co miał z nami robić”. Jak podkreślał, Czapów „niczego takiego wielkiego nie zrobił - a po wojnie robił z siebie bohatera, publikując w PAX-ie swoje wspomnienia z czasów wojny". Bardzo szybko opuścił zresztą struktury NSz, oskarżając tę organizację o współpracę z Niemcami, co przyczyniło się do poważnego konfliktu pomiędzy organizacjami działającymi na terenie Sandomierza. Ponadto za kradzież archiwum i rowerów NSZ został „skazany na śmierć”

W trakcie dalszych moich poszukiwań badawczych okazało się, iż historia „nie lubi próżni”. W tej sprawie „mógł się zatem wypowiedzieć” także Czesław Czapów. Potwierdzenie tej historii odnalazłam bowiem w aktach Instytutu Pamięci Narodowej, w których w jednym z oświadczeń napisał on:

pierwszy kontakt z ruchem podziemnym, jaki nawiązałem latem $1943 \mathrm{r}$. w Sandomierzu, gdzie wówczas mieszkałem przy ojcu, był kontakt ze środowiskiem endeckim. Przez kilka tygodni byłem związany z komórką NSz-u. Zorientowawszy się jednak, że mam do czynienia z propagandą za kościołem narodowym, co godziło we mnie jako katolika oraz zetknąwszy się z wyraźnym nawoływaniem do mordowania Żydów porzuciłem kontakt i „przeciągnąłem" prawie wszystkich znanych mi chłopców do AK. Wówczas anoni-

8 M. Zielonka, Narodowe Sity Zbrojne, cz.1, http://www.nowastrategia.org.pl/narodowe-sily-zbrojne-czesc-1/, dostęp 15.12.2019.

9 Wywiad z Januszem Kamocki ps. „Mamut”, 30 maja 2018. 
mową drogą zagrożono mi biciem. A kiedy udało mi się, przy pomocy ludzi z AK, wykraść archiwum Komendy NSZ oraz odebrać i przekazać do AK enezetowskie rowery, radia i broń, zagrożono mi śmiercią ${ }^{10}$.

W dalszej części owego oświadczenia czytamy, że będąc już w IV kompanii II batalionu 2 pułku Piechoty Legionów AK, jego kompania

rozbiła koło Czajkowa jedyną większą na terenie Sandomierszczyzny grupę NSZ-u. Stosunki natomiast z AL w tym czasie, w którym ja byłem, układały się poprawnie. Pamiętam dwa wspólne postoje i ogólne rozmowy z żołnierzami AL. W naszych oddziałach byli Francuzi, Rosjanie, Żydzi, a nawet jeden Niemiec antyhitlerowiec. W AK uczęszczałem do szkoły podoficerskiej, ale stopnia nie uzyskałem. Gdy ojciec mój został aresztowany, a ja uciekłem z miasta i wstąpiłem do partyzanckiego oddziału AK Orlicza ${ }^{11}$.

\section{Dywersja Obwodu Sandomierz i oddział „Orlicza”}

Obwód Sandomierz obejmował swym obszarem teren powiatu sandomierskiego. Powiat ten w tamtych latach (jak i dziś) był typowo rolniczy i słabo zalesiony. Przez obwód przechodziła linia kolejowa Skarżysko-Ostrowiec Świętokrzyski-Rozwadów. Oznaczony był on kryptonimami: „Ziarno”, „Wyżyny”, „Eukaliptus”, „Henryk” i wchodził wraz z Obwodem Opatów w skład Inspektoratu Sandomierskiego. Sam obwód dzielił się na pięć podobwodów, które z kolei miały po trzy lub cztery placówki, pokrywające się z granicami gmin.

Działania konspiracyjne rozpoczęto w powiecie już w pierwszych miesiącach okupacji hitlerowskiej. Początkowo - do kwietnia 1941 r. działalność dywersyjną organizował Związek Odwetu. W połowie 1943 r. powstały oddziały partyzanckie, które poza dywersją prowadzily także otwartą walkę z Niemcami. Jednocześnie zarówno komendant obwodu, jak i komendanci poszczególnych podobowdów mieli w swej dyspozycji patrole bądź oddziały dywersyjne ${ }^{12}$.

10 Instytut Pamięci Narodowej [dalej: IPN], syğn. IPN BU 00 1043/3928, Zespół Ministerstwo Spraw Wewnętrznych II, Oświadczenie, k. 14.

11 Tamże.

12 W. Borzobohaty, „Jodła”. Okręg radomsko-kielecki zWZ-AK 1939-1945, Warszawa 1988, S. $177-181$. 
Jednym z takich oddziałów partyzanckich powstałych w tamtym okresie był oddział "Orlicza” - Lotna Grupa Bojowa ${ }^{13}$ - powstały w początkach lipca 1943 r. Wybór padł na Łoniów, wieś położoną o 23 km na południe od Sandomierza. Powstała placówka miał w swych założeniach pełnić funkcję zalążka oddziału partyzanckiego. Komendantem tej placówki był podch/ppor. Adam Hamerski - „Babinicz”, a dowódcą placówkowego oddziału dywersyjnego najpierw sierż. Antoni Mazgaj, a po nim sierż. Stefan Franaszczuk - „Tarzan”, który później zmienił pseudonim właśnie na „Orlicz" ${ }^{\prime 14}$. Broń dla oddziału dostarczyły placówki, m.in. Koprzywnica -8 kb.

Zdjęcie 1. Tablica pamiątkowa Lotnej Grupy Bojowej AK-Sandomierz, która w dniu 26 września 1999 r. została wmurowana na kościele parafialnym p.w. Św. Mikołaja w Łoniowie, upamiętniająca utworzenie w tej miejscowości w 1943 r. oddziału partyzanckiego Lotna Grupa Bojowa AK Sandomierz

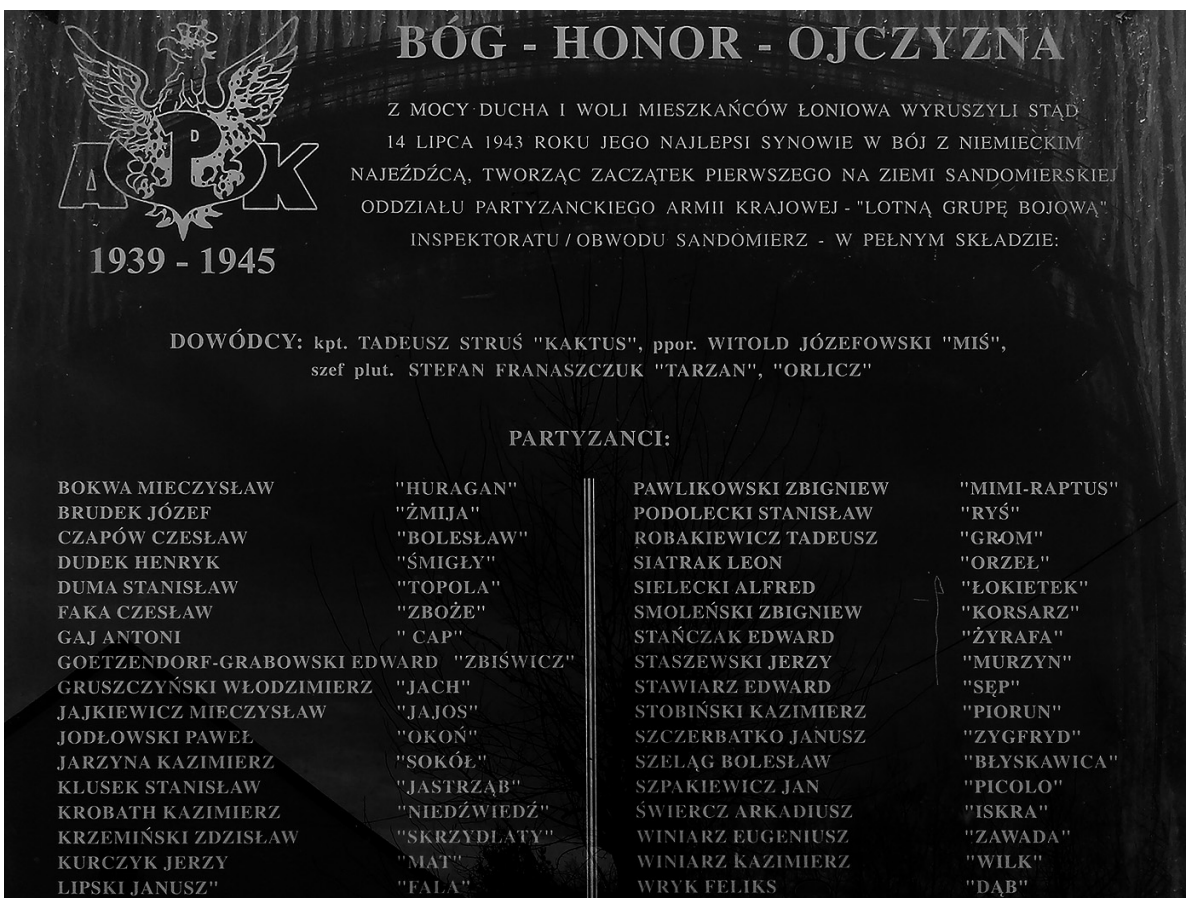

13 Pełna nazwa to oddział partyzancki Inspektoratu AK Sandomierz- Lotna Grupa Bojowa, popularnie zwana także Lotną Sandomierską.

14 W. Gruszczyński, Lotna Sandomierska. Dzieje oddziału partyzanckiego, Warszawa 2003, s. 57-59. 
W skład oddziału wchodzili m.in. Bolesław Szeląg „Błyskawica”, Mieczysław Gaj „Cap”, Mieczysław i Zbigniew Pawlikowscy „Ghandi” i „Raptus-Mimi”, Henryk Zarzycki „Grab”, Włodzimierz Gruszczyński „Jach”, Zbigniewa Smoleński „Korsarz”, Marian Mazgaj „Kozak”, Tadeusz Cebo „Lelek”, Roman i Henryk Nowakowscy „Mściciel” i „Nałęcz”, Włodzimierz Milbert „Pat”, Kazimierz Stobiński „Piorun”, Jan Spasowicz „Pikolo”, kpr. Kazimierz Jarzyna „Sokół”, Jan Osemlak „Straceniec”, Kazimierz i Eugeniusz Winiarze „Wilk” i „Zawada”, Mieczysław Jajkiewicz „Jajas”, Jerzy i Zbigniewa Rolscy „Babinicz” i „Boruta” oraz Czapów „Bolek-Falenica”15 - znany także pod pseudonimem „Bolesław”16. Oddział przeciętnie liczył 20-30 żołnierzy, a jego uzbrojenie w większości stanowily karabiny ${ }^{17}$.

„Grupa Lotna” wykonała m.in. wiele akcji na terenie obwodu sandomierskiego:

- Listopad 1943 r. - „Grupa Lotna” w sile 12 żołnierzy pod dowództwem kpt. „Kaktusa” opanowała w centrum Sandomierza koszary specjalnego oddziału nawigacji lotniczej i Bahnschutzpolizei dla zdobycia broni i amunicji. Plan budynku dostarczył wywiad obwodu. Atak nastąpił po zmroku i po rozbrojeniu wartownika oddział wtargnął do budynku, zajmując niemal wszystkie pokoje. Zabito i raniono kilku Niemców, a pozostałych rozbrojono. Zdobyto w ten sposób dużo broni, amunicji oraz sprzętu wojskowego. Oddział nie poniósł strat.

- Listopad 1943 r. - oddział w sile ok. 20 żołnierzy pod dowództwem kpt. "Kaktusa” zaatakował liczącą 42 żołnierzy załogę ochrony mostu kolejki wąskotorowej w Szczucinie. Celem ataku było zdobycie broni i amunicji. Po rozbrojeniu wartowników rozpoczęło się natarcie na budynek, które zakończyłoby się jego opanowaniem (Niemcy przygotowywali się już do kapitulacji), gdyby nie nadciągnęła niespodziewana odsiecz. W walce odwrotowej 4 ludzi zostało rannych, natomiast po stronie niemieckiej było łącznie 14 zabitych i rannych. Pościg niemiecki nie dał żadnych rezultatów, wszyscy żołnierze grupy zdołali się wycofać, zdobywając nawet kilka KB.

- Maj 1944 r. - oddział „Lotna Grupa” pod dowództwem „Orlicza” zorganizował w lesie majątku Skrzypaczowice na szosie Łoniów-Koprzywnica zasadzkę na szefa

15 E. Dąbrowski, Szlakiem Jędrusiów, s. 401.

16 W. Gruszczyński, Lotna Sandomierska, s. 332.

17 M. Sołtysiak, Moje wspomnienia, „Wieś, 20 (1948) s. 27. 
placówki Gestapo w Sandomierzu von Paula. Akcja się nie powiodła, von Paul zdołał uciec, rozbito jedynie jego kilkunastoosobową osłonę. W lipcu 1944 r. von Paul został ujęty przez patrol likwidacyjny inspektoratu Sandomierz pod dowództwem pchor. „Waltera” (Józef Bojanowski), który ponownie zorganizował zasadzkę w tym samym miejscu. Von Paula po przesłuchaniu rozstrzelano.

- Maj 1944 r. - „Grupa Lotna” uczestniczyła w odbiorze zrzutu na placówce „Pomidor” w okolicy Wiązownicy, koło wioski Granicznik. Wzięło w tym udział ok. 15 ludzi pod dowództwem "Misia” (Witold Józefowski) i kilkunastu "Jędrusiów”. Zrzut przyjmował ppor. „Wielopolski” (Paweł Sowiński). Całością dowodził kpt. „Siwy” (Michał Mandziara). Po przyjęciu zrzutu oddział „Misia” odskoczył ze sprzętem, „Jędrusie" natomiast, ubezpieczając odskok, odciągnęli pościg niemiecki w przeciwnym kierunku ${ }^{18}$.

Wyżej przedstawione wydarzenia szerzej opisane zostały przez Włodzimierza Gruszczyńskiego „Jach”, członka „Grupy Lotnej”, a potem „Jędrusiów” w jego wspomnieniach ${ }^{19}$, w których przytacza także nazwisko Czesława Czapówa. Możemy w nich odnaleźć także zapiski o trudach partyzanckiego życia, które dla tych młodych chłopców wiązało się nie tylko z niedostatkiem uzbrojenia, ale także z nieustannym brakiem funduszy na utrzymanie oddziału. Uwidaczniało się to przede wszystkim w okresie jesieni i zimy, gdy zaczynały się nad wyraz „brutalnie” uwidaczniać niedostatki w jedzeniu, bieliźnie, cieplejszej odzieży i obuwiu. Jednocześnie w trudnych, niemal koczowniczych warunkach życia niełatwo było utrzymać należytą higienę, co sprzyjało pojawianiu się wszelkich pasożytów i chorób. Pomimo tych trudności był to jednocześnie czas kontynuowania nauki. Jak podkreśla Gruszczyński, to dzięki temu, i „wbrew nieprzyjacielskim dążeniom", udało się ochronić przed wyniszczeniem w sferze kulturalnej i naukowej ogromną część młodzieży, z której wyrosły po wojnie kadry nauczycielskie, profesorskie, naukowe, a także wysokiej klasy specjaliści różnych dziedzin życia gospodarczego oraz rodzimi ludzie sztuki i literatury ${ }^{20}$.

18 Wojciech Borzobochaty zaznacza, iż w rozdziale napisanym o Obwodzie Sandomierskim korzystał m.in. z materiałów przesłanych przez Czesława Czapówa: W. Borzobohaty, „Jodła", s. 184-185.

19 W. Gruszczyński, „Lotna Sandomierska”: wspomnienia partyzanta, Kielce 1999; oraz „Odwet-Jędrusie": próba monografii, Staszów-Tewa, Kielce 1999.

20 Tegoż, Lotna Sandomierska, s. 76. 
O swych doświadczeniach w oddziałach partyzanckich na Kielecczyźnie wspomniał niejednokrotnie swym kolegom-współpracownikom ${ }^{21}$ także sam Czapów, o czym możemy przeczytać we wspomnianej już przeze mnie książce zredagowanej przez p. Wandę Kaczyńską. O swych doświadczeniach wojennych wspominał również w swoich życiorysach pisanych chociażby z okazji zdobywania kolejnych stopni naukowych ${ }^{22}$. Jednak najbardziej cenne wydaje się kalendarium akcji organizowanych przez „Lotną Sandomierską” napisane po wojnie przez Czapówa, ukazujące, w których akcjach jego autor uczestniczył. Owe zapiski zachowały dzięki żonie - Gabrieli Czapów, która po śmierci męża w 1980 r. przekazała je Jerzemu Rolskiemu „Babinicz”. Obdarowany wspomina o tym w liście napisanym do swego kolegi z oddziału, Włodzimierza Gruszczyńskiego „Jach". Gruszczyński otrzymał je wraz z owym listem 10 kwietnia 1984 r. i umieścił w domowym archiwum dotyczącym „Lotnej Sandomierskiej”23. Po śmierci Gruszczyńskiego rodzina przekazała je do kieleckiego oddziału Instytutu Pamięci Narodowej24, dzięki czemu udało się je odnaleźć.

Z tych zapisków wynika, że Czapów uczestniczył nie tylko w akcjach wspomnianych wcześniej, ale także wielu innych.

- Sierpień 1943 r. - „Grupa Lotna” likwiduje w ciągu jednej nocy wszystkie niemieckie ogłoszenia i znaki drogowe na trasie Osiek-Sandomierz (32 km);

- 15.09.1943 r. - „Grupa Lotna” opodal Faliszowic, w wąwozie gęsto zarośniętym drzewami i krzewami zaatakowała oddział granatowych policjantów jadących na furmankach. Słaby opór policjantów załamał się po krótkiej walce wręcz. Policjantów puszczono wolno zabierając im karabiny austriackie starego typu z amunicją oraz kilka granatów. Akcją dowodził Stefan Franaszczuk, który wówczas miał pseudonim „Tarzan” i zmienił go później na ps. „Orlicz”.

21 Owe wspomnienia można odnaleźć pośród wielu opowiadań m.in. S. Manturzewskiego, na łamach wspomnianej już przeze mnie książki Czesław Czapów. 1925-1980. Świadectwa trzech pokoleń pod redakcją W. Kaczyńskiej.

22 Na przykład Archiwum Uniwersytetu Warszawskiego, sygn. wPP- hab. 1, 55, Zespół Akta przewodu habilitacyjnego, Czapów Czesław, k. 17, 21.

23 IPN Ki 182/10, cz.1, teczka: Korespondencja Włodzimierza Gruszczyńskiego dot. jego książki „Lotna Sandomierska”.

24 IPN Ki 182/10, cz.1, teczka: Korespondencja Włodzimierza Gruszczyńskiego dot. jego książki „Lotna Sandomierska”. 
- Koniec września 1943 r. - „Grupa Lotna” opanowuje most na Wiśle w Szczucinie i zdobywa bunkier ochrony kolejowej. Po stronie niemieckiej: 14 zabitych i rannych. Po stronie polskiej: jeden zabity i 5 rannych. W czasie zdobywania bunkra Józef Gaj („Cap”) ciężko ranny od kul i odłamków (z wystrzelonym jednym i uszkodzonym drugim okiem) zostaje wyniesiony z pola walki przez „Pioruna”. Na moście pod Szczucinem zostaje ciężko ranny w brzuch Bolesław Szeląg („Błyskawica”). Sierżant „Orzeł” wraz z amunicyjnym „Picolo” likwiduje z erkaemu pierwszą linię atakujących żandarmów [...] uniemożliwiając ogniem poderwanie się hitlerowców do ponownego natarcia. Mając odciętą drogę przez most torują sobie drogę granatami [...] i łódką przeprawiają się na drugą stronę Wisły gdzie dołączają do grupy. „Sęp” ranny na moście strzela aż do wyczerpania amunicji przetrzymując atak żandarmów. Zadaniem akcji było zdobycie umocnień ochronnych niemieckiego oddziału ochrony mostu i kolei w celu zniszczenia urządzeń [...] przygotowanych do wysadzenia mostu. W tym cele żołnierze „Grupy Lotnej” dźwigali (sporządzone osobiście przez „Kaktusa”) dużych rozmiarów minę.

- Grudzień 1943 r. - akcja „Grupy Lotnej” na więzienie w Sandomierzu w godzinach między 5-7 rano. Jak pisze C. Czapów „atak nie udaje się ze względu na zdradę strażnika więziennego, który nie odsunął zasuwy w bramie. Po sforsowaniu skarpy i ogrodzenia oddział zastał zamkniętą bramę, dostając się pod niespodziewany ogień straży więziennej, do której wkrótce dołączyła żandarmeria i oddział ochrony mostu, a następnie inne jednostki niemieckie. Józef Bojanowski „Walter” skutecznie powstrzymuje kontr-atak żandarmów, ułatwiając oderwanie grupy od nieprzyjaciela. Następnie szybki odskok... bez strat własnych ${ }^{25}$.

To surowe partyzanckie życie, wypełniane licznymi akcjami „zrównało” partyzantów wspólną dolą i wytworzyło grunt, na którym zrodziły się przyjaźnie niezależnie od pochodzenia społecznego, a przede wszystkim wzajemna życzliwość i zażyłość, która trwała wiele lat po wojnie, a która właściwa jest dla towarzyszy broni. W życiu codziennym różnice stały się prawie niewidoczne, zatem można powiedzieć, że nic nie mąciło harmonii w tym dość szczególnym zbiorowisku ludzi o bardzo zróżnicowanych cechach osobistych: o dużej rozpiętości wykształcenia, o ogromnym zróżnicowaniu kultury osobistej, odmiennym sposobie myślenia, o różnych doświadczeniach i zainteresowaniach, zwyczajach

25 Tamże, k. 249-268. 
i nawykach, o różnych sposobie wyrażania myśli, a także o odmiennych programach na życie po wojnie. Zatem, co warto podkreślić, w tej tak raczej przypadkowo skleconej społeczności nie występowały sprzeczności interesów, a właśnie ich pełna zgodność co do jednego, a istotnego - uczestnictwa w walce z wrogiem. Dlatego też z pełnym zrozumieniem i akceptacją spotkała się decyzja komendy Inspektoratu Okręgowego Sandomierz o połączeniu „Lotnej Sandomierskiej” z oddziałem "Jędrusiów".

\section{„Jodła”26 w czasie „Burzy”}

Jak pisze Czapów w książce Sprawy Armii Krajowej, która miała zostać wydana w 1957 r. (do czego nigdy nie doszło) i której maszynopis udało się odnaleźć:

działania bojowe Armii Krajowej noszące nazwę „Burza” rozpoczynają się w styczniu 1944 r., a kończą właściwie w październiku tegoż roku. Polegały one na zmasowanym uderzeniu wszystkich oddziałów partyzanckich, dywersyjnych oraz posiadających broń oddziałów konspiracyjnych na niemieckie garnizony, linie kolejowe i odwody. Stanowily one szereg lokalnych i częściowych powstań realizowanych siłami zdolnymi do natychmiastowej walki. Uderzenie na danym terenie miało następować dopiero z chwilą zbliżania się Armii Czerwonej. Bezpośrednim bowiem celem akcji „Burza” była pomoc nacierającym oddziałom radzieckim. W ten sposób Armia Krajowa miała zademonstrować swoją silę i wystąpić jako gospodarz zajmowanych przez Armię Czerwoną terenów ${ }^{27}$.

„Nie zdobi nas mundur, nie chwali nas sztab, Ni krzyżem z nas żaden znaczony, Śmierć tylko odznakę bojowa nam da-My szare Jędrusia plutony". (to jest cytat z Szewera T., Straszyński O., Niech wiatr ją poniesie: antologia pieśni z lat 1939-1945, Łódź 1975, s. 346)Powyższe słowa są fragmentem znanego hymnu "Jędrusiów". Wyrażają one w lapidarnym skrócie swoistą atmosferę tego samodzielnego, autonomicznego oddziału partyzanckiego, w którym to, jak wynika z analizowanych wspomnień jego członków, nigdy nie przyjęły się stop-

26 „Jodła” - była kryptonimem wszystkich oddziałów Armii Krajowej Okręgu Kielecko-Radomskiego. W akcji „Burza” w okresie powstania warszawskiego oddziały „Jodły” przejawiały olbrzymią prężność organizacyjną oraz bojowość.

27 Archiwum Akt Nowych, sygn. 76/III-22, zespół Opracowanie, Czapów Czesław, Sprawy Armii Krajowej, Biblioteczka „Po prostu", 1957, k. 115. 
nie, odznaczenia czy czysto zewnętrzna dyscyplina. Był to zatem oddział, który w pamięci jego partyzantów zapisał się piękną kartą wysoko cenionego koleżeństwa bojowego, równością uprawnień i obowiązków, a przede wszystkim świadomą - w pełnym tego słowa znaczeniu - dyscypliną wewnętrzną.

Zdjęcie 2. Zdjęcie przedstawiające maszynopis książki Czesława Czapówa Sprawy Armii Krajowej, Biblioteka „Po Prostu”, 1957.

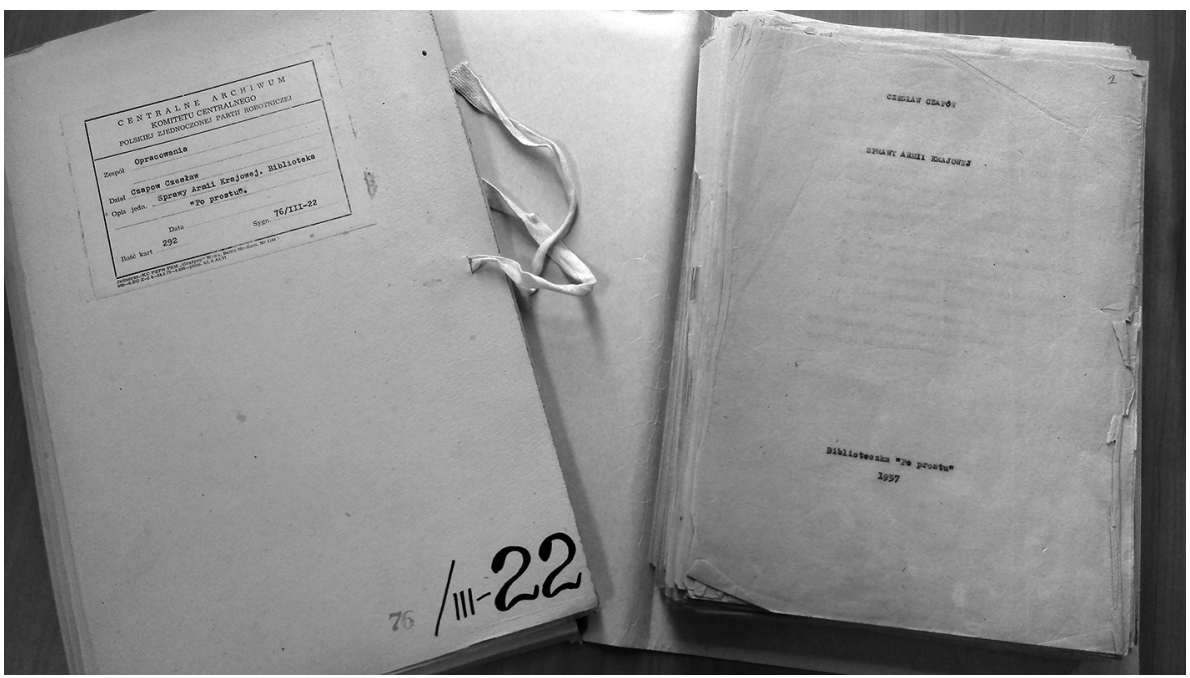

Jak już wspomniałam, już w początkowym okresie okupacji, do kwietnia 1941 r., działalność dywersyjną na terenie obwodu prowadził Związek Odwetu. Założył go Władysław Jasiński - student Uniwersytetu Warszawskiego. W obwodzie - z inicjatywy Jasińskiego - działała także samodzielna grupa "Jędrusiów". Powstała ona już w październiku 1939 r. w powiecie tarnobrzeskim, przyjęła zaś nazwę „Polska Organizacja Partyzancka”, a następnie „Odwet”. To właśnie z niej wyłoniono na wiosnę 1941 r. oddział dywersyjno-bojowy „Jędrusie". "Odwet” istniał nadal jako organizacja.

W latach 1942-1944 - do momentu rozpoczęcia akcji „Burza” oddział pod dowództwem "Jędrusia" - Władysława Jasińskiego (Jasiński, wraz z dwoma żołnierzami, zginął 9 stycznia 1943 r. otoczony przez żandarmerię we wsi Trzcianka), a następnie „Sowy” - Józefa Wiącka - dokonał wielu akcji bojowych, z których najważniejsze były: 
- likwidacja w grudniu 1942 r. z wyroku wss konfidenta Cukierskiego w Bogorii k. Staszowa;

- wykonanie wyroku śmierci w grudniu 1942 r. na Pawle Gorczyckim w Gołoszycach;

- rozbicie więzienia w Opatowie 12 marca 1943 r. i w Mielcu 29 marca 1943 r.; w obu tych akcjach ppor. „Sowa" dowodził siłami "Jędrusiów" i żołnierzy z miejscowych komórek AK; w pierwszym przypadku uwolniono około 80 więzionych, w drugim - około 180;

- rozbrojenie posterunku policji granatowej w Bogorii;

- rozbrojenie Niemców w Koprzywnicy i Bogorii;

- walki z żandarmerią w Łoniowie, Osieku i Strużkach;

- wykonanie 24 października 1943 r. wyroku śmierci na agencie Gestapo Gaszyńskim;

- zaatakowanie na początku marca 1944 r. przez patrol z oddziału „Jędrusiów” pod dowództwem „Romka Uszatego" - Józefa Szelesta grupy 10 Niemców, jadących pociągiem kolejki wąskotorowej w kierunku Szczucina;

- likwidacja 17 marca 1944 r. przez sześcioosobowy patrol pod dowództwem „Franka” - Franciszka Rutyny na rynku w Koprzywnicy w dzień targowy 4 żołnierzy patrolu niemieckiego ${ }^{28}$.

12 czerwca 1944 r. w Lesisku ${ }^{29}$ nastąpiło połączenie „Grupy Lotnej” z „Jędrusiami”.

Stefan Franaszczuk „Orlicz” i Józef Wiącek "Sowa” oddali sobie - w obecności kapitana Tadeusza Strusia - „Kaktus” - honory wojskowe, wypowiedzieli odpowiednie formuły, po czym „Orlicz" podszedł do szeregu swoich byłych podkomendnych i, salutując, podał każdemu rękę. W tym mocnym i serdecznym uścisku mieściło się podziękowanie za wspólną walkę i za wspólną służbę oraz życzenie, aby kule omijały na dalszych wojennych ścieżkach. Z kolei „Sowa” objął komendę nad całością. - Baczność!. Zmieszać się! - padła nieregulaminowa komenda... ${ }^{30}$.

28 E. Dą̧browski, Bez broni, Warszawa 1969, s. 40-130.

29 Taką datę znajdujemy w książce W. Gruszczyńskiego, tamże, s. 228. Z kolei Eugeniusz Dąbrowski w książce Szlakiem Jędrusiów (s. 351) pisał, iż to połączenie oddziałów miało miejsce w kwietniu. Jednocześnie obaj wymieniają nazwisko Czapówa jako tego, których do „Jędrusiów" został przeniesiony.

30 W. Gruszczyński, Lotna Sandomierska, s. 228. 
W grupie "Jędrusiów" znalazł się oczywiście Czapów. Partyzanci, którzy nie dołączyli do "Jędrusiów", otrzymali inne przydziały służbowe w miejscowych organizacjach konspiracyjnych, w których tworzono głęboko utajone struktury przygotowane na czas spodziewanej okupacji niemieckiej. Jednocześnie już w lipcu 1944 r. (w związku organizacją planu „Burza”, która na Sandomierszczyźnie został zarządzony 20 lipca 19944 r. w związku z dojściem frontu wschodniego nad Wisłę) utworzono z nich 2 Pułk Piechoty Legionów Armii Krajowej, który 28 lipca 1944 r. na szosie Osiek-Staszów w Turskim Lesie uczestniczył w zasadzce, podczas której zlikwidowano sztab niemieckiego 4 pułku saperów z 4 Armii Pancernej, zdobywając broń i plany umocnień hitlerowskich na linii Nida-Pilica. Poległo wówczas 7 oficerów niemieckich. W akcji brał udział Czapów, co barwnie opisał Tadeusz Szewera, ukazując swego kolegę jako osobę z poczuciem humoru oraz dużym dystansem do własnych działań:

Biegnę ostatni z „Bolkiem-Falenicą”, ubezpieczając od tyłu drużynę. Kule z giwizdem tną gałęzie. Naraz „Bolek” przysiada, twarz ma szarą, wykrzywioną. Chyba dostał? Chwytam go pod pachy, wlokę kilkadziesiąt metrów. Pot zalewa mi czoło. Naszych już nie ma, zostaliśmy sami. Tracę siły. Sadzam go więc drzewem, plecami opieram o pień. Co robić dalej, Bóg mi świadkiem, że nie wiem. Dźwigać go nie dam rady, zostawić samego w lesie nie pozwala żołnierski obowiązek.... Tymczasem strzelanina cichnie, widocznie wojsko dotarło do rozbitych amfibii i trupów. Między drzewami migają dwie sylwetki. To nadbiegają „Edmund” $i$ „Jerzy”. Robi mi się raźniej. Ustawiamy cekaem przy pniu, zakładamy nowiutką taśmę. W razie czego nie sprzedamy życia tak tanio. Teraz możemy już pomyśleć o „Bolku- Falenicy", który słabiutkim głosikiem prosi: - Zdejmijcie mi buty. Nogi moje, nogi... A więc dostał po nogach. Paskudna historia. Próbujemy ściągnąć mu cholewy kawaleryjskim sposobem. „Bolek” jęczy, buty ani drgną. Wówczas "Jerzy" postanawia przeciąć cholewy nożem. Mimo rozpaczliwych protestów „Bolka” rozpłatał je tak ślicznie, że zleciały z nóg jak listki z drzewa. Ku naszemu zdumieniu i wściekłości żadnych ran od kul na nogach „Bolka” nie było. Tylko na piętach czerwieniły się wielkie placki po obtartej skórze. Takie piękne buty, a tak mnie urządziły, że nie mogłem uciekać - tłumaczył się „Bolek”, gdyśmy go klęli w „żywy kamień”. [...] Doganiamy pluton w pobliżu Rybnicy [...] Przy bramie swej kwatery stoi dowódca batalionu kpt. „Tarnina” z dowódcą naszej kompanii „Józkiem”. Pada komenda: baczność! Na prawo patrz! Walimy butami, aż się kurzy. To nasza pierwsza partyzancka defilada. Tylko „Bolek-Falenica” błyska gołymi stopami. Pac, pac, 
klepie zabawnie piach. Czuję, że lada moment parsknę śmiechem i będzie skandal. Na szczęście dowódca plutonu daje komendę: spocznij! I składa meldunek z akcji, przekazując mapy i jeńców. W dowództwie radość. Mapy są bardzo cenne, wyznaczony jest na nich plan niemieckich umocnień obronnych na przyczółku sandomierskim i w całym okręgu radomsko-kieleckim [...]. Otrzymujemy pochwałę za męstwo i rozchodzimy się na kwatery. Zmęczeni, bez słowa zakopujemy się w siano. Tylko „Bolek Falenica” zasypiając, jeszcze marudzi: - Patrz, bracie, takie buty, a taka kompromitacja. Żeby chociaż miały większą stopę... ${ }^{31}$.

Dnia 13 lipca 1944 r. 1 Front Ukraiński, dowodzony przez marszałka Iwana Koniewa, w ramach operacji lwowsko-sandomierskiej, rozpoczął ofensywę w kierunku Wisły. Otrzymał on z Kwatery Głównej Armii Radzieckiej zadania sforsowania Wisły w rejonie Sandomierza i uchwycenia tam przyczółku w pierwszych dniach sierpnia 1944 r. 30 lipca 1944 r. przyczółek rozszerzono na $12 \mathrm{~km}$ szerokości i $8 \mathrm{~km}$ głębokości. 1 sierpnia Niemcy zaatakowali zdobyte przez Rosjan pozycje z kierunku Koprzywnica-Sandomierz i Klimontów. W walkach z oddziałami niemieckimi w rejonie Dmosic i Staszowa wziął udział 2 pp $\mathrm{AK}^{32}$. Uczestniczył w nich również Czapów ${ }^{33}$.

2 pp AK osłaniał swą akcją północne skrzydło wojsk radzieckich, które w tym czasie przeprawiały się przez Wisłę. Równocześnie oddziały 2 pp AK wsparły oddziały radzieckie walczące o Łoniów i Koprzywnicę. W ten sposób oddziały AK umożliwiły marsz wojsk radzieckich w kierunku Staszów-Bogoria i Staszów-Łagów. Oddziały radzieckie, operujące na przyczółku sandomierskim, nie były zbyt liczne. Akcja akowskiej piechoty stanowiła więc szczególnie cenną pomoc. Chodziło bowiem o to, by utrzymać przyczółek, zanim nadciągną większe siły radzieckie. I w tej fazie walk o przyczółek sandomierski oddziały 2 pp AK wzięły czynny udział. W pierwszych dniach sierpnia oddziały radzieckie i oddziały AK stoczyły bitwę o Staszów. Miasto kilkakrotnie przechodziło z rąk do rąk. Wreszcie hitlerowcy wycofali się. Wkrótce potem oddziały AK zaatakowały niemieckie oddziały pod

31 T. Szewera, Buty „Bolka Falenicy”, „Za Wolność i Lud”, 1958, nr 10 (127), s. 8-9.

32 W. Tuszyński, Realizacja planów operacyjnych AL $w$ działaniach partyzanckich na Lubelszczyźnie i Kielecczyźnie, Przegląd Historyczno-Wojskowy, 22 (1962) s. 115.

33 IPN BU OO 1043/3928, k. 14. 
Bogorią. Po tych walkach Rosjanie i Polacy rozpoczęli ruch w kierunku Łagowa. [...] 2 pp AK nie długo tkwił pod Łagowem. Rozkaz komendanta Okręgu Radom płk Zientarskiego „Mieczysława” skierował go na teren koncentracji 2 dp AK. Dywizja ta miała wejść w skład grupy wojsk idących na odsiecz walczącej Warszawie ${ }^{34}$.

Natomiast zacięte walki na przyczółku trwały nieprzerwanie do końca sierpnia 1944 r. Front ustabilizował się na sześć miesięcy. 15 stycznia 1945 r. z przyczółka sandomierskiego wyszła kolejna, wielka ofensywa Armii Radzieckiej. Ta akcja była bowiem najważniejszym elementem całej operacji lwowsko-sandomierskiej ${ }^{35}$. Jego doniosłą rolę doceniał także szef sztabu głównego Wehrmachtu, Heinz Guderian, który uważał, iż stanowił on dużą groźbę dla Niemców, a Hitler wręcz nazywał go pistoletem wymierzonym w pierś III Rzeszy ${ }^{36}$.

Czapów w tym trudnym czasie pozostał w pamięci swych towarzyszy broni także jako osoba, która potrafiła uatrakcyjnić życie żołnierskie pod względem kulturalnym. Wiadomym jest, że w wielu kompaniach swe umiejętności prezentowali lokalni odtwórcy skeczów i monologów, akrobaci, poeci czy muzycy. „W 2 pp AK niewątpliwie wyróżniał się st. strz. Czesław Czapów, który wraz z kolegą st. strz. Zbigniewem Smoleńskim („Korsarz”) wykonywał wiele skeczów ku uciesze kolegów z 2 pp AK"37.

\section{Sierpień 1944. Odsiecz}

„Rozkaz odsieczy Warszawy wydano 14 sierpnia 1944 r. Poszły na Warszawę oddziały z Obszaru Warszawa, z obwodów Ziemi Radomskiej, Kieleckiej i z Okręgu Łódź. Szły nawet zbrojne grupy z Rzeszowszczyzny i ze Śląska [...] Brałem udział w tym marszu” ${ }^{38}$. Pierwsza mobilizacja Okręgu dała „Mieczysławowi” (Jan Zientarski-Liziński) około 6 ooo ludzi. Byli to wszystko żołnierze

34 AAN, sygn. 76/III-22, k. 157.

35 A. Greczko, Niektóre zagadnienia sztuki wojennej w operacji lwowsko-sandomierskiej Armii Radzieckiej, Wojskowy Przegląd Historyczny 6 (1961) nr 1, s. 210.

36 H. Guderian, Wspomnienia żołnierza, Warszawa 1958, s. 303.

37 P. Sierant, Działalność Służ Pułkowych w 2. Pułku Piechoty Legionów Armii Krajowej $w$ zarysie, Lublin 2002, s. 27.

38 Cz. Czapów, Sierpień 1944. Odsiecz, „Dookoła Świata”, 1957, nr 33 (190), s. 14. 
uzbrojeni. Brakowało jednak broni przeciwpancernej, przeciwlotniczej i artylerii. Niezbyt bogate były zapasy amunicji. Nastąpiła koncentracja wszystkich oddziałów. Maszerujący żołnierze szli w trudnych warunkach aprowizacyjnych, nieustannie walcząc z Niemcami. Każde niemal przejście większej artylerii komunikacyjnej kończyło się walką. Pułki 2 i 72 oraz oddział kawalerii dywizyjnej 2 dp szły do rejonu Nowego Miasta. Jak podkreśla i co miało wówczas ogromne znaczenie, były to niemal wyłącznie marsze nocne. Chodziło bowiem o to, aby utrudnić Niemcom właściwe rozeznanie ruchów i sił Korpusu. Opóźniało to jednak bardzo tempo marszu ${ }^{39}$.

W nocy z 18 na 19 sierpnia 2 pułk przekroczył linię kolejową i szosę Kielce-Skarżysko, 19 sierpnia w lasach koło Świniej Góry nastąpiło spotkanie z 4 pułkiem, po czym obydwie jednostki podążyły do lasów chlewiskich. Przy przekraczaniu szosy Szydłowiec-Niekłań, idący jako szpica czołowa pluton z kompanii „Habdanka” strzałem z piata zniszczył samochód wojskowy. Sześciu żołnierzy niemieckich zginęło, 4 odniosło rany. W ręce partyzantów dostało się 2 karabiny maszynowe, 13 karabinów i 2 pistolety. W lasach koło Niekłania do kolumny marszowej dołączył 3 pułk. Następnie w ciągu dwóch następnych nocy wszystkie trzy jednostki osiągnęły rejon lasów przysuskich. 2 pułk rozbił biwak w pobliżu wsi Rusinów, w jego sąsiedztwie, w lesie koło Bryzgowa, zatrzymał się 4 pułk, w pobliżu Zapniowa zaś stanął 3 pułk. Trzeba jednak podkreślić, że prawie połowa żołnierzy nie miała żadnego uzbrojenia. W dodatku oddziały nie miały broni przeciwlotniczej, ale posiadali przeciwpancerną oraz w minimalnych ilościach ciężkie i lekkie karabiny maszynowe. Dotarcie tego rodzaju odsieczy do Warszawy stawało się bardzo problematyczne. Przekroczywszy Pilicę, oddziały wyszłyby bowiem na bezleśny teren powiatu grójeckiego, a starcie w otwartym polu z nieprzyjacielem wyposażonym w samoloty i czołgi - do którego niewątpliwie musiałoby dojść - z góry przesądzało wynik bitwy. Jeżeli nawet oddziałom partyzanckim udałoby się przebić okalający Warszawę pierścien, to skrwawione i wyczerpane walką nie byłyby w stanie odciążyć powstańczej załogi Warszawy. Zdając sobie z tego sprawę, a jednocześnie nie mając wewnętrznego przekonania o realności odsieczy, płk „Mieczysław” uzależniał dalszy marsz w kierunku stolicy od otrzymania dużych zrzutów broni

39 Cz. Czapów, Sierpień 1944. Odsiecz, „Dookoła Świata”, 1957, nr 33 (190), s. 14. 
maszynowej, przeciwpancernej i amunicji. Ponieważ baza zrzutowa we Włoszech, wysyłając w owym czasie samoloty przede wszystkim nad Warszawę, nie była w stanie zaspokoić żądań komendanta Okręgu Kielce, 21 sierpnia zarządzono wstrzymanie marszu na północ ${ }^{40}$.

Czapów pisze, iż

[...] wielkie jednostki niemieckie rozlokowały się w rejonie Pilicy, starając się zablokować drogę do Warszawy. Ruszyła w rejon Pilicy niemiecka dywizja pancerna [...]. Obroną tego rejonu zajął się sam von dem Bach. Słuchałem go, kiedy zeznawał w procesie gubernatora dystryktu warszawskiego Fischera. Powiedział wtedy, że powstrzymanie oddziałów powstańczych idących od południa na odsiecz Warszawy było centralnym zagadnieniem bitwy o Warszawę, toczonej w drugiej połowie sierpnia 1944. Rzucono ponadto na teren Okręgu Kielce szereg hitlerowskich oddziałów, rosyjskich, ukraińskich, kozackich i mongolskich, które szerzyły gwałt wśród ludności polskiej i utrudniały dalsze koncentrowanie sił Okręgu. [...] W gajówce Promień odbyła się narada, która zdecydowała o dalszych losach marszu. Wzięli w niej udział Dowódca Korpusu płk. „Mieczysław” (Zientarski). Jego szef sztabu płk dypl. „Wojan” (Borzobochaty), dowódca $2 \mathrm{dp}$ płk „Lin” Żółkiewski oraz dowódca 7 dp płk dypl. "Czesław" (Gawiński). Większość członków narady zdecydowała wstrzymanie dalszego marszu. 27 VIII gen. Komorowski zaakceptował tę decyzję, rozkazując Korpusowi Kieleckiemu zaatakowanie Radomia lub Kielc, albo też tych punktów, które mogły mieć wpływ na odwrót Niemców. Ale i te zalecenia nie zostały wykonane. Nie pozwoliła na to dalsza koncentracja sił niemieckich oraz wielki brak amunicji, którą odczuwały oddziały Korpusu. "Mieczysław” postanowił więc rozdzielić oddziały Korpusu i wykonywać wzmożoną akcję „Burza” na własnym terenie. Akcja odsieczy Warszawy zakończyła się niepowodzeniem. Hitlerowskie wojska przystąpiły do ostatecznej likwidacji Korpusu Warszawskiego ${ }^{41}$.

A jakie były dalsze losy Czapówa? W dokumentach Instytutu Pamięci Narodowej () czytamy:

40 B. Hillebrandt, Partyzantka na Kielecczyźnie 1939-1945, Warszawa 1970, s. 411-414.

41 Cz. Czapów, Sierpień 1944. Odsiecz, „Dookoła Świata”, 1957, nr 33 (190), s. 18-19. 
Wraz z dywizją Ziemi Kieleckiej dotarłem do Pilicy, a następnie po częściowej demobilizacji, jako chory i niezdolny do marszu, opuściłem oddział. Było to pod Małogoszczą w listopadzie 1944 r. [...] Po kilkutygodniowym pobycie w jakimś majątku koło Małogoszczy udałem się do Woli Załężnej pod Opocznem, gdzie wówczas przebywała moja matka /Rodzice moi się rozeszli i matka moja wyszła za mąż za sędziego grodzkiego, Witolda Romera, urzędującego w Opocznie. W czasie okupacji Witold Romer był członkiem AK i na wiosnę 1943 r. został przez hitlerowców aresztowany i zamęczony w obozie w Majdanku/. W Woli Załężnej ciężko chorowałem aż do przyjścia Armii Czerwonej. Następnie przez kilka miesięcy pracowałem jako kreślarz w opoczyńskim urzędzie ziemskim. A potem udałem się do Kielc, gdzie ojciec mój był naczelnikiem wydziału drogowego w Urzędzie Wojewódzkim. W Kielcach uzyskałem świadectwo dojrzałości i udałem się do Warszawy na studia ${ }^{42}$.

Zadanie udokumentowania i opisania losów Czesława Czapówa w oddziałach partyzanckich na terenie obecnego województwa świętokrzyskiego okazało się niesłychanie trudne. Niełatwo przecież podążać za człowiekiem tyle lat po zakończeniu wojny, a przede wszystkim 40 lat po jego śmierci. Zwłaszcza, że Ci, którzy mogli coś w tę historię wnieść, sami odeszli. Jednak krok po kroku udało się tę drogę odtworzyć. Co ciekawe, z zebranych dokumentów wynika, że kontakt ze swymi kolegami z oddziału Czapów utrzymywał aż do swojej śmierci w 1980 r. Zapewne nie przyznawał się do tego. Jak wynika z Kroniki „Jędrusiów”, tworzonej po wojnie przez Eugeniusza Dąbrowskiego, a mającej na celu dokumentowanie losów partyzantów w okresie okupacji, jak i po jej zakończeniu, Czapów uczestniczył niemal we wszystkich poczynaniach: spotkaniach, sympozjach, które były organizowane. Złożył się także na budowę pomnika upamiętniającego poległych „Jędrusiów” w Sulisławicach w 1957 r., zasilając zbiórkę kwotą 100 złotych.

42 IPN BU 1043/3928, s. 14-15. 
Zdjęcie 3. Zapis z Kroniki Jędrusiów potwierdzający przekazanie 100 zł na budowę pomnika w Sulisławicach - „Falenica”

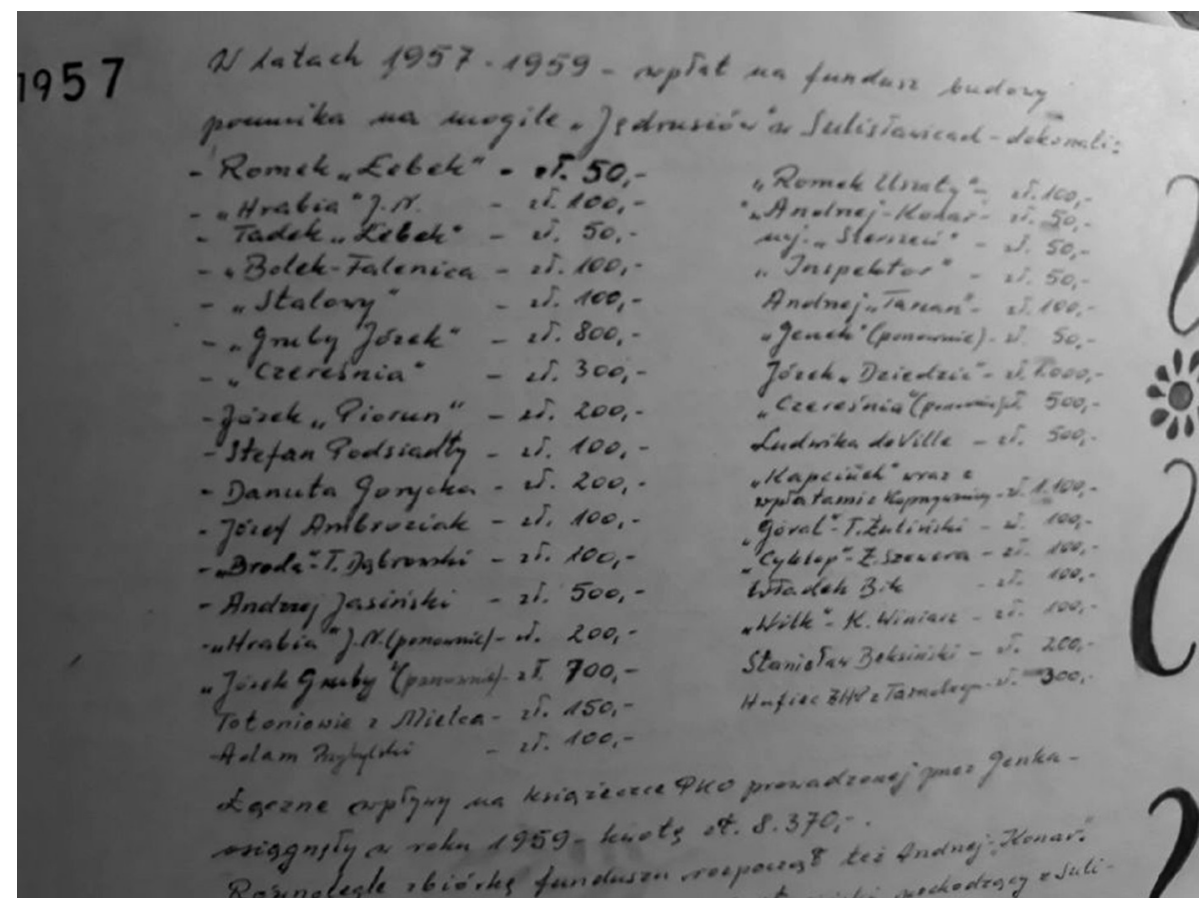

Gdy w latach siedemdziesiątych XX w. Eugeniusz Dąbrowski rozpoczął gromadzenie zdjęć i dokumentów, aby utworzyć Izbę Pamięci „Jęrusiów”, która obecnie znajduję się w byłej zakrystii XIII w. kościoła w Sulisławicach ${ }^{43}, \mathrm{Cza}^{-}$ pów przesyłał mu materiały i swoje zdjęcie, które obecnie znajduje się na tablicy pamiątkowej.

43 Izba Pamięci „Jędrusiów” została otwarta 8 września 1981 r. Urządził ją ks. Stanisław Suwała, honorowy kapelan „Jędrusiów". 
Zdjęcie 4. Czesław Czapów wśród kolegów z oddziału „J̨drusie” - tablica pamiątkowa - Izba Pamięci „Jędrusiów" - kościół w Sulisławicach

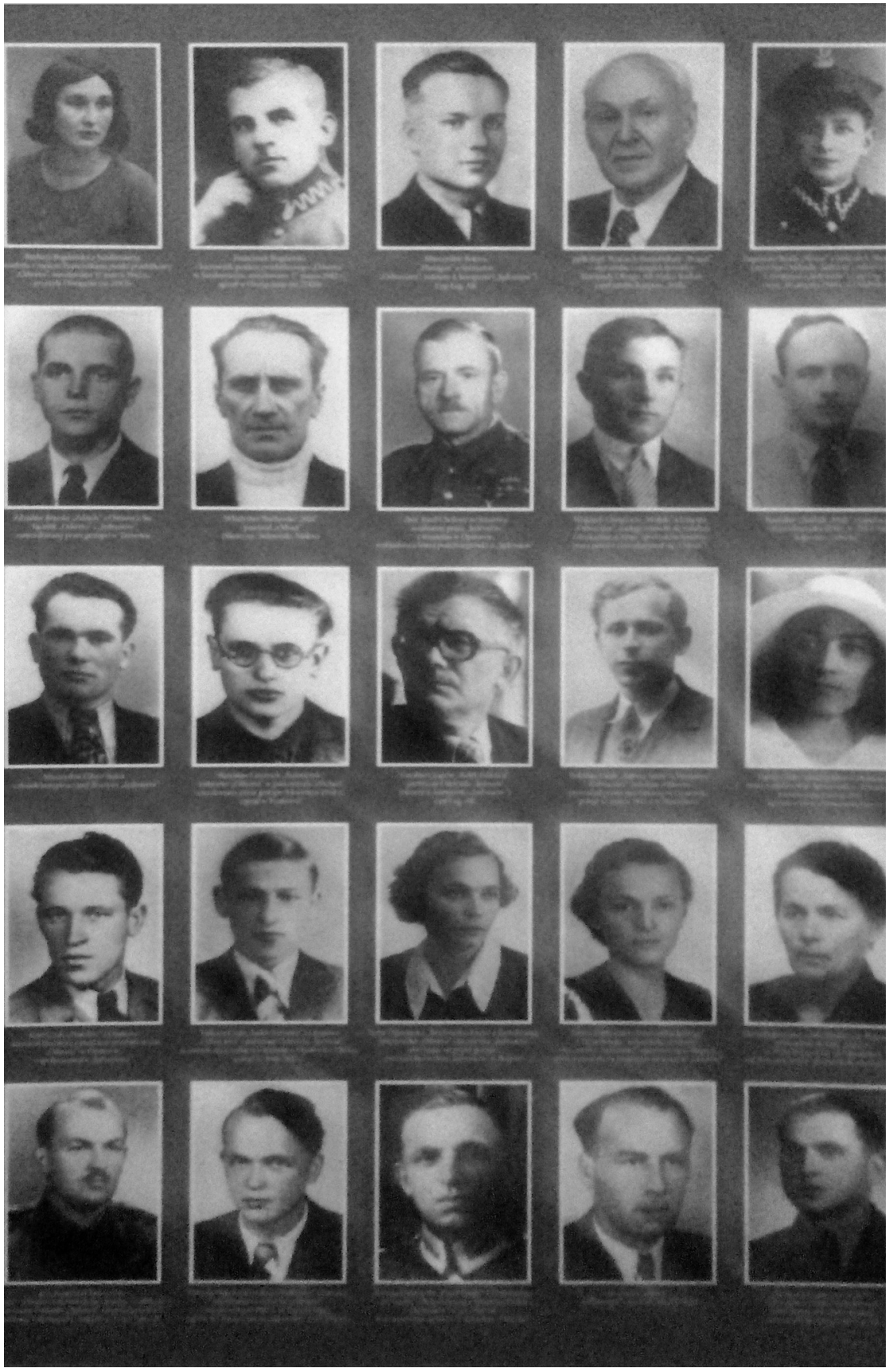


W Kronice "Jędrusiów" odnaleźć można także nekrolog napisany po śmierci Czesława Czapówa w 1980 r. przez członków oddziału "Jędrusie”, który dla nas niech stanie się swoistym świadectwem, a jednocześnie naszym podziękowaniem za jego trud i poświęcenie, które na zawsze naznaczyły jego życie.

Zdjęcie 5. Nekrolog Czesława Czapówa znajdujący się w Kronice Jędrusiów.

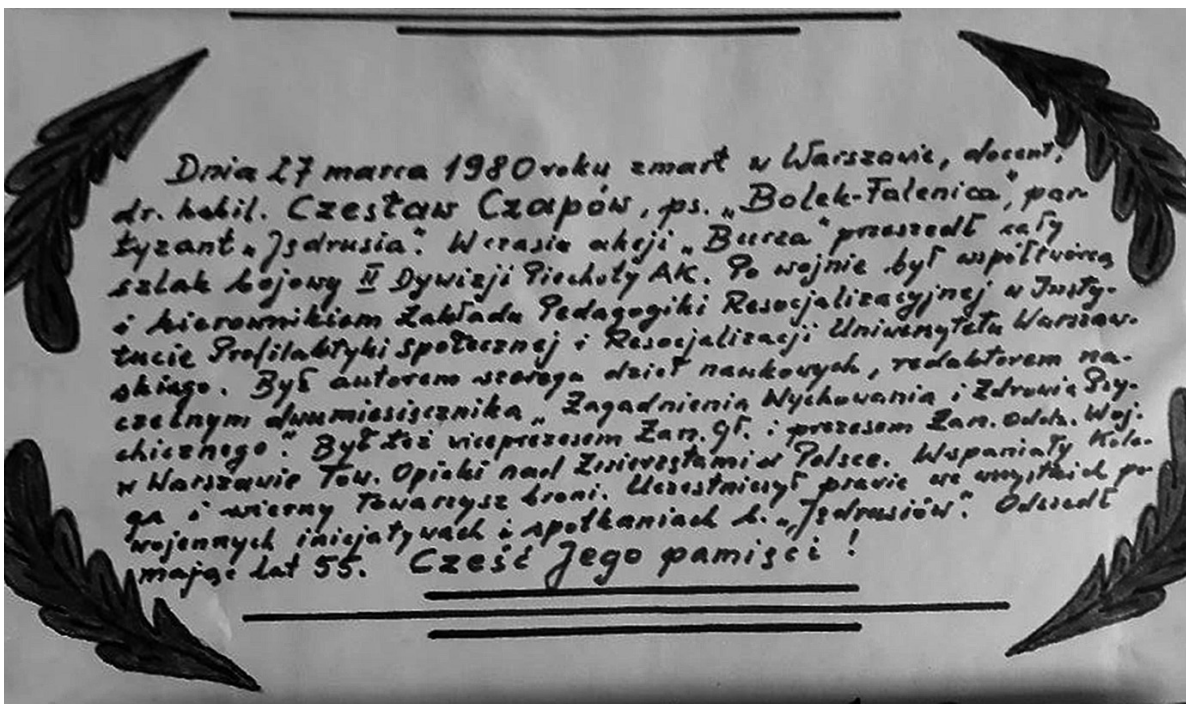

Streszczenie: Czesław Czapów z Uniwersytetu Warszawskiego zapisał się na stronach polskiej nauki jako twórca warszawskiej szkoły resocjalizacji. W 2020 roku, minęło 20 lat od Jego nagłej, przedwczesnej śmierci. Pozostawił po sobie wybitne dzieła, które po dziś dzień stanowią podstawową lekturę z zakresu nauk o resocjalizacji. Pozostał także w pamięci swych kolegów, którzy tak naprawdę niewiele wiedzą o Jego życiu prywatnym, czy wczesnych latach dzieciństwa. Prezentowany tekst ma na celu przybliżenie jednego z bardzo interesujących (a zarazem zupełnie nieznanych) wątków z życia Czesława Czapówa, a mianowicie Jego działalności w oddziałach partyzanckich podczas II wojny światowej na Kielecczyźnie. Jednocześnie stanowi on fragment przygotowywanej większej pracy związanej z Jego osobą. Prowadzone badania wpisują się w nurt badań jakościowych, a ich specyfika wymaga zastosowania swoistej metodologii zbierania danych, opartych na badaniach historycznych, biograficznych, historyczno-oświatowych, historyczno-pedagogicznych. Zastosowałam przy tym triangulację metod i danych. Źródłem informacji o działalności Czesława Czapówa w czasie II wojny światowej, na podstawie których opracowałam poniższy tekst są materiały źródłowe, archiwalne, artykuły z prasy, dokumenty i fotografie, wywiad oraz dostępna literatura przedmiotu w omawianej tematyce. 
Słowa kluczowe: Narodowe Siły Zbrojne, Armia Krajowa, odziały partyzanckie, Lotna Bojowa Sandomierska, „Jędrusie”.

\section{Bibliografia}

\section{Źródła}

Archiwum Akt Nowych, sygn. 76/III-22, zespół: Opracowania. Dział: Czapów Czesław, Opis jednostki: Sprawy Armii Krajowej. Biblioteka „Po prostu”, 1957, k. 292.

Archiwum Uniwersytetu Warszawskiego, sygn. WPP-hab. 1, 55, Zespół Akta przewodu habilitacyjnego, Czapów Czesław.

Instytut Pamięci Narodowej, sygn. IPN BU 00 1043/3928, Zespół Ministerstwo Spraw Wewnętrznych II, Oświadczenie.

Instytut Pamięci Narodowej, sygnn. IPN Ki 182/10, Zbiór: Włodzimierz Gruszczyński, Korespondencja Włodzimierza Gruszczyńskiego dot. jego książki „Lotna Sandomierska", cz. 1.

\section{Opracowania}

Borzobohaty W., „Jodła”. Okręg radomsko-kielecki ZWZ-AK 1939-1945, Warszawa 1988.

Dąbrowski E., Bez broni, Warszawa 1969.

Dąbrowski E., Szlakiem „Jędrusiów”, Warszawa 1966.

Dąbrowski E., Szlakiem „Jędrusiów”, Warszawa 1969.

Czapów C., Sierpień 1944. Odsiecz, „Dookoła Świata”, 1957, nr 33 (190), s. 14-15, 18-19.

Greczko A., Niektóre zagadnienia sztuki wojennej w operacji lwowsko-sandomierskiej Armii Radzieckiej, „Wojskowy Przegląd Historyczny”, 6 (1961) nr 1, s. 205-223.

Gruszczyński W., „Lotna Sandomierska”: wspomnienia partyzanta, Kielce 1999.

Gruszczyński W., „Odwet-Jędrusie”: próba monografii, Staszów - Tewa, Kielce 1999.

Gruszczyński W., Lotna Sandomierska. Dzieje oddziału partyzanckiego, Warszawa 2003.

Guderian H., Wspomnienia żołnierza, Warszawa 1958.

Hillebrandt B., Partyzantka na Kielecczyźnie 1939-1945, Warszawa 1970.

Czesław Czapów 1925-1980. Świadectwa trzech pokolen, , zebr., oprac., red. W. Kaczyńska, Warszawa 2003.

Komorowski K., Polityka i walka. Konspiracja zbrojna ruchu narodowego 1939-1945, Warszawa 2000.

Matusak P., Ruch oporu na ziemi opatowsko-sandomierskiej w latach 1939-1945, Warszawa 1976.

Muszyński W. J., W walce o Wielka Polskę. Propaganda zaplecza politycznego NSZ 19391945, Warszawa 2000. 
Sierant P., Działalność Służ Pułkowych w 2. Pułku Piechoty Legionów Armii Krajowej w zarysie, Lublin 2002.

Siemaszko Z. S., Narodowe Siły Zbrojne, Londyn 1982.

Sołtysiak M., Moje wspomnienia, „Wies”, 20 (1948) s. 27.

Szewera T., Buty „Bolka Falenicy”, „Za Wolność i Lud”, 1958, nr 10 (127), s. 8-9.

Szewera T., Straszyński O., Niech wiatr ją poniesie: antologia pieśni z lat 1939-1945, Łódź 1975.

Tuszyński W., Realizacja planów operacyjnych AL w działaniach partyzanckich na Lubelszczyźnie i Kielecczyźnie, „Wojskowy Przegląd Historyczny”, 22 (1962) s. 93-134.

Zielonka M, Narodowe Siły Zbrojne, cz.1, http://www.nowastrategia.org.pl/narodowe-sily-zbrojne-czesc-1/, dostęp 15.12.2019. 